Meta

Journal des traducteurs

Translators' Journal

\title{
Ad Hoc Court Interpreters in the United States: Equality, Inequality, Quality?
}

\section{Nancy Schweda-Nicholson}

Volume 34, numéro 4, décembre 1989

URI : https://id.erudit.org/iderudit/004074ar

DOI : https://doi.org/10.7202/004074ar

Aller au sommaire du numéro

Éditeur(s)

Les Presses de l'Université de Montréal

ISSN

0026-0452 (imprimé)

1492-1421 (numérique)

Découvrir la revue

Citer cet article

Schweda-Nicholson, N. (1989). Ad Hoc Court Interpreters in the United States: Equality, Inequality, Quality? Meta, 34(4), 711-723.

https://doi.org/10.7202/004074ar d'utilisation que vous pouvez consulter en ligne. 


\title{
AD HOC COURT INTERPRETERS IN THE UNITED STATES: EQUALITY, INEQUALITY, QUALITY?
}

\author{
NANCY SCHWEDA-NICHOLSON \\ University of Delaware, Delaware, U.S.A.
}

\section{INTRODUCTION}

In a review of the translation and interpretation literature, one rarely finds scholarly articles which focus on the process and problems of court interpretation. In fact, Roberts (1981: Appendice bibliographique) writes that there are "très peu de sources de référence traitant spécifiquement de l'interprétation auprès des tribunaux." In an attempt to partially address the need for research in this area, the current article focuses on (1) ad hoc interpreter use for non-English-speakers in the American judicial system; (2) why professional court interpretation training is needed; and (3) what content areas must be included in any course or program. It concludes by outlining strategies not only for developing training opportunities but, ultimately, for solving the problems inherent in the use of ad hoc interpreters.

The Court Interpreters Act of 1978 (Public Law 95-539) has made great strides in the fight to ensure due process for non-English-speaking as well as deaf or hearingimpaired defendants in criminal and civil cases initiated by the United States Government (Ingram, in press; Schweda-Nicholson 1985b). However, at the state and local levels, interpretation services are often non-existent or inferior due to lack of organization, lack of qualified interpreters, insensitivity to the issue on the part of judges and other courtroom personnel, the relative powerlessness of the groups which need the service, and/or lack of funds. Perhaps this final reason is the most significant one, as the author's research shows that even those state and local courts which have attempted to provide interpretation services when necessary often rely on the goodwill of volunteers because there is no money budgeted to pay them. Moreover, each state faces different organizational problems because state court systems are not all structured in the same way.

\section{WHY THE COURT IS NOT THE BEST “JUDGE" OF INTERPRETERS}

It is unfortunate but true that the need for interpretation services has not always been taken seriously by the courts. There are numerous documented federal, state, and local cases in which either no interpreter was provided (for any number of reasons) or the person who was called upon to act as the ad hoc interpreter was a bilingual bailiff, a friend or relative of the defendant, a friend of the judge, a police officer, a spectator in the courtroom, and so on. A major problem with the use of such ad hoc interpreters is that there is usually no way to assess the foreign language competence of the individual. As the great majority of our American judges are monolingual English-speakers, most of them are in no position to accurately evaluate the abilities of the person chosen.

The foreign language competence of an ad hoc interpreter is the most obvious skill to question. However, one must also consider the consecutive and simultaneous interpretation abilities of such a person. Also important is the individual's familiarity with courtroom procedure and legal terminology. Unfortunately, most laypersons labor under the 
misconception that anyone who has even rudimentary knowledge of a foreign language can automatically interpret. This is simply not true. Even people who are completely bilingual may not make good interpreters. The reason for this is that there are other factors which play a role in the development of interpretation skills in addition to language ability, such as personality, flexibility of mind, ability to think on one's feet and analyze quickly, broad general knowledge, cultural awareness, level of education, and so on (Schweda-Nicholson 1984). Except in a very small percentage of cases, the development of the above skills requires professional training. In addition to academic preparation for court interpreters, education of judges and other courtroom personnel as to the specialized nature of interpretation is imperative so they may come to realize exactly what is involved in this very complex task.

\section{THE USE OF AD HOC COURT INTERPRETERS}

The following sections will examine various courtroom situations in which ad hoc interpreters have been used, and will illustrate the consistently disastrous consequences. The material is divided according to the groups of people that are often called upon to interpret. Pertinent federal and state cases will be mentioned as they relate to the use of a particular kind of person as the ad hoc interpreter.

\section{A. RELATIVES, FRIENDS, AND SPECTATORS}

Judges commonly appoint or allow relatives and friends of a defendant to act as ad hoc interpreters (Astiz 1980: 19; Hippchen 1977: 263; Sollmann 1984: 3). This procedure is often a very easy and convenient one for the court because friends and/or relatives of the accused may be present as spectators in the courtroom, and there is no need for the judge to recess or continue the case until an interpreter can be located. To reiterate, the problem with this method of selecting a person to serve as an interpreter in that he/she (1) may not possess the requisite English and/or foreign language skills; (2) probably has no formal interpretation training; and (3) may know nothing at all about courtroom procedure, legal terminology, or the concepts behind the "legalese" inherent in any courtroom proceeding. These are heavily-weighted considerations, especially when someone's life and liberty are at stake, which is very often the case. A May 10, 1983 Washington Post editorial referred to this very problem:

Court administrators are usually able to find a Spanish speaker somewhere in the social services bureau to help out in court. But this kind of ad hoc response can fail... (A-18)

Sometimes, the judge him/herself may bring in a friend to interpret (Garland 1981b). Or, he/she may simply ask if there is anyone in the courtroom who speaks Spanish (Garland 1981a). During a very recent case, State v. Gonzalez-Gongora 673 S.W.2d 811 (Mo. 1984), the court allowed a friend of the defendant to act as his interpreter. The record indicated that the friend was present throughout the trial. However, the convicted man appealed because the court "allowed" his friend to interpret for him, but did not officially "appoint" him to act as such (816). The appellant claimed that, during his trial, he was "inhibited in his ability to comprehend the proceedings and communicate with counsel" (816). In this case, the appeal was denied because the friend was present during all phases of the trial and it was obvious from the court record that the defendant had agreed to have his friend interpret for him. Moreover, the fact that the court did not officially "appoint" the friend to perform as the interpreter did not constitute reversible error. In a 1981 case, however, Boston Municipal Court Judge Charles Grabau refused to permit a relative of the defendant to act as his interpreter. He stated: 
Personally, I won't allow it... Just imagine if you spoke French and you were on trial, and you asked me to let your sister interpret for you. How do I know for sure what you're saying. You might say, "Yes, I did it," and she would say, "I was never there" (Garland 1981b: 18).

As demonstrated above, some courts feel that a defendant's right to a competent, independent interpreter may be waived, while others regard the requirement of a professional interpreter as too fundamental for waiver.

\section{B. COURT PERSONNEL}

Collectively, the group of people probably called upon most often to act as ad hoc interpreters are court personnel (Hippchen 1977: 263; Safford 1977: 26). They include bilingual bailiffs, receptionists (Marrone 1982: 5), secretaries (Astiz 1980: 19), and even defense attorneys. (For a detailed discussion of defense attorneys as interpreters, see Section $F$ under the current heading.)

Quite often, court personnel are pressed into service against their will. Many such people have stated that they know they are not qualified to interpret. On the other hand, these individuals sometimes fear for their jobs if they do not agree to participate in this way. For example, in refusing a judge, one can be held in contempt of court. Employing professionally-trained interpreters would certainly be a solution to this problem, but that is much easier said than done.

Here, as in all such cases, the question of due process arises. If the quality of interpretation services at the state and local levels is generally poor, then the guarantee of due process rights of those individuals requiring interpretation must also be poor. Should a non-English-speaker tried in a state court be entitled to fewer rights than a non-Englishspeaker tried in a federal court? Certainly not, at least to the extent that the defendant's rights in federal court are dictated by the United States Constitution, relevant parts of which are binding upon the states. Indeed, a defendant's rights in state court may be even greater than in federal court, for some states interpret state constitutional provisions identical to parts of the federal constitution in a manner more liberal than the federal judiciary's view of the corresponding federal constitutional provisions.

In Bustillos v. State 464 S.W.2d 118 (Tex. Crim. App. 1971), a clerical employee in the Lubbock County Attorney's Office was called to serve as the ad hoc interpreter during the trial. On appeal, the appellant objected to the use of this clerical employee because she was part of the "law enforcement team" (126). However, the appellate judge did not view the use of a partisan interpreter as reversible error, and the original conviction of "assault with intent to murder" was affirmed.

In a very recent case, State v. Laureano 682 P.2d 889 (Wash. 1984), an employee of the county sheriff's department was allowed by the trial judge to act as the interpreter (902). The judge did not view this as an abuse of discretion even though the potential for prejudice was obvious.

As with any court or law enforcement-affiliated employee whose major function is other than that of interpreter, acting as an interpreter is a secondary duty (Anderson 1978: 221; Marrone 1982: 3; Sollmann 1984: 2-4, 7). Furthermore, because these people are officially employed in a different capacity, they are not compensated for their work as interpreters. Such situations only serve to promulgate the idea that interpreters are not to be taken seriously as professionals. In many courts' eyes, anyone can do it.

The author's research also includes numerous examples of using bilingual bailiffs as ad hoc interpreters. One must also raise the question of conflict of interest in such a situation. Sollmann (1984) writes about a bilingual bailiff employed by the Municipal Court in Wilmington, Delaware. During Sollmann's interview with the bailiff, the bailiff 
commented that the clients often view her as taking the side of the court. They don't trust her. They are afraid that she is not telling the court everything they are saying. They worry that she may be prejudicing their case against them. The bailiff admitted that, during one case at which she was called to interpret, a man pleaded guilty to a crime of which he was not guilty because he did not understand English and the bailiff had not been able to explain the charges well enough in Spanish so that he would comprehend.

\section{POLICE OFFICERS}

Another group to consider is police officers. They are very often called on by the court to act as interpreters (see, for example, Garland 1981b: 18; Safford 1977: 25). Once again, the potential for prejudice presents itself. A police officer is usually a key witness for the prosecution. As such, the ethical considerations of having a person in that position interpret for a defendant are numerous. A May 5, 1983 Washington Post article entitled, "Hispanics Lack Parity in Court System", stated:

Sometimes Spanish-speaking police officers are pressed into service as translators, but defense attomeys claim they are biased toward the prosecution (Valente 1983: A-12).

Sollmann writes that, at the Municipal Court in Wilmington, Delaware, "Puerto Rican police in the street may be available, but they are not permitted to translate because they may be biased" (1984: 3). Furthermore, in Gonzales v. State 372 A.2d 191 (De. Supr. $\mathrm{Ct}$.), the Delaware Supreme Court reversed a judgement against the defendant because an arresting police officer served as the accused's intepreter both at the time of the arrest and during the trial. The Supreme Court held that "there is an inherent possibility of bias" (192) in such a situation.

\section{UNPAID VOLUNTEERS}

Due to budgetary constraints, many courts are forced to rely on the services of volunteers when interpreters are needed. The American Association of University Women (AAUW) is often contacted to provide ad hoc interpreters (Latimer 1983: B-1; Marrone 1982: 3). As a rule, the AAUW women are well-educated, which is a positive factor when one considers the sophisticated language of the courts. Sometimes, the AAUW volunteers are foreign nationals. Having been born in a foreign country can also be very helpful, because a good understanding of the cultural differences between the United States and the foreign country can prove invaluable for interpreters.

In Delaware, the Latin American Community Center in Wilmington is sometimes called to provide interpretation services (Marrone 1982: 11; Sollmann 1984: 5). At times, these volunteers are paid by the courts; other times, they are not.

In the Washington, D.C., metropolitan area, police departments and the courts use volunteer interpreters from the United Way, the Red Cross, and other social service agencies (Latimer 1983: B-1). Local governments and police departments in Prince George's, Montgomery, and Fairfax counties, as well as in the District of Columbia, keep a running list of people who are willing to assist them as interpreters. They are always looking for additional multilingual volunteers.

As is understandable when one considers the requisite qualifications for professional interpreters, volunteers are not a good solution to the interpretation problem. Deputy Chief Judge Levinberg of the New Castle County, Delaware Magistrate Court indicated that "he was displeased with the interpreters on the [volunteer] list, as those contacted were often uninterested in assisting in the court system" (Marrone 1982: 11). 


\section{E. PAID VOLUNTEERS}

Sometimes, volunteer interpreters are paid by the court itself or by the defense attorney in need of their services. There are many sources for these volunteers. University personnel from foreign language departments are often contacted (Sollmann 1984: 5). As well, scientists from the Du Pont Company are called to work in the Delaware courts (Marrone 1982: 15; Sollmann 1984: 8). Personnel from La Comunidad Hispana, a social service agency in Kenneth Square, Pennsylvania, often serve as ad hoc interpreters in the courts of the southern part of Chester County, Pennsylvania. For their services, they are paid \$15 per case (Sollmann 1984: 9).

As mentioned previously, the problem with employing volunteer interpreters is that, almost invariably, these people do not have any formal interpretation training. They may have no conception of the ethics involved, not to mention language difficulties in either or both English and the foreign language. (Ethics will be discussed in more detail in Part IV.)

\section{F. DEFENSE ATTORNEYS}

Even though it may seem surprising, bilingual defense attorneys are often instructed by the judge to act as both counsel and interpreter for their client (see, for example, Astiz 1980: 19). In this way, the defense attorney is required to wear two hats simultaneously, which is quite impossible. Mr. Samuel Delgado, a Hispanic public defender in the Superior Court of the District of Columbia, told the author in an interview that he is often pressed into service to act as an interpreter for his client. When he is so instructed by a judge, he usually protests. In doing so, he requests that the trial record indicate that he assumes the interpreting responsibility against his will. Mr. Delgado told the author that this occurrence is a very common one. In the District of Columbia Superior Court, there are 60 public defenders. He is the only Hispanic. There is one other non-Hispanic public defender who speaks Spanish as well. Mr. Delgado is often assigned to those cases which are brought against a Spanish-speaking defendant. Some of the judges simply assume that, because Mr. Delgado is a Spanish-speaker, it is only natural that he act as the interpreter for his client. Chang and Araujo (1975: 822) write: $\ldots$ the bilingual attorney is in the undesirable position of translating the proceedings to the
defendant while at the same time attempting to formulate and discuss strategy and tactics.

In People v. Martinez 7 III. App. 3d 1075, 289 N.E.2d 76 (1972), the Illinois Court of Appeals affirmed the judgement against the defendant even though his attorney acted as his interpreter. However, courts seem to be becoming more sensitive to the fact that a defense attorney cannot play both these roles at the same time. In State v. Rios 112 Ariz. 143, 539 P. 2d 900 (1975) and People v. Chavez 124 Cal. App. 3d 215, 177 Cal. Rptr. 306 (1981), defense attorneys were not allowed to function as interpreters for their clients. The court judged that playing this dual role impaired the lawyers' ability to provide an adequate defense. The opinion in State $v$. Rios illustrates this dilemma very effectively:

For defense counsel to cross-examine witnesses, listen attentively to testimony and objection[s] of the prosecuting attorney and hear rulings and remarks of the presiding judge and simultaneously render an accurate and complete translation to his three clients, is an impossible task. The effectiveness of defense counsel under those circumstances is obviously greatly impaired to the serious detriment of his climents' defense $(144,901)$. 


\section{G. WITNESSES AND CO-DEFENDANTS}

Perhaps more unbelievable than having a defense attorney act as an interpreter for his/her client is having a prosecution witness or a co-defendant play that role. However, in People v. Rivera 13 III. App. 3d 264, 300 N.E.2d 869 (1973), the Illinois Court of Appeals affirmed the conviction for unlawful possession of narcotics even though a codefendant had acted as an interpreter. In Green v. State 260 A.2d 706 (Del. 1969), the appellate court upheld the decision of the lower court even though an interpreter who had been officially designated by the Trial Court to interpret testimony for the victim was also called on as a witness for the prosecution. Justice Herrmann, dissenting, wrote:

... [I]t was prejudicial error to permit the interpreter, designated as such at the request of the State to translate the testimony of the victim, to testify as a prosecution witness as to the facts of the case. A person designated and sworn by the Court as the interpreter for the trial becomes part of the Court's "team" momentarily and is cloaked with officialdom in the eyes of the jury... It should be the rule, in my opinion, that the interpreter designated by the Trial Court should be disqualified as a witness, especially in a criminal case tried before a jury (708).

The fact that many courts do not view (and have not viewed) professional interpretation services as a requirement to ensure due process for the non-English-speaker is evident from the above examples. However, it should be noted that some progress has been made during the past several years in a number of state and local courts. More judges seem to be attuned to the needs of the defendant who does not understand or speak English. Much credit for this growing awareness is owed to the Court Interpreters Act. It mandates the use of highly qualified interpreters in criminal and civil trials which are brought by the United States Government. As well, the Act has established a Spanish/English Certification Program in order to identify those individuals who are capable of this very demanding work. A roster of the interpreters who pass the Spanish/English examination is distributed to all district courts on an annually updated basis so judges, clerks of the court, and others are fully aware of the people in their area who are certified as interpreters for use in the federal courts. Unfortunately, the Act has as its jurisdiction the federal courts only, so it does not apply in state courts. With the advent of state legislation addressing this very serious need, it is hoped that ad hoc interpreters will become a thing of the past (Schweda-Nicholson 1985b).

\section{WHY COURT INTERPRETER TRAINING IS NEEDED}

\section{A. INTRODUCTION}

The Court Interpreters Act of 1978 has helped to establish a professional status for court interpreters in the federal courts. The Act has also contributed to a greater awareness on the part of court and non-court personnel of the role and responsibilities of the interpreter in a courtroom. It has established very high standards for court interpreters in Spanish-English through its certification program. In doing so, this statute has made great strides in the war against due process violations when non-English-speaking defendants are involved. Even though the Court Interpreters Act has forced the federal courts to take interpretation services more seriously and has, in only seven years, had far-reaching consequences, it is by no means complete in its mandates for the courts.

For example, the Act does not provide for training of interpreters to be used in the federal courts (see, for example, Arjona 1983: 4). Interestingly enough, though, an announcement for the "Court Interpreters Certification Written Examination, Spanish/ English" contains the following paragraph: 
Qualifications: There are no formal educational requirements for certification, either in languages or interpreting. However, the difficulty of the bilingual examination is at the college degree level of proficiency and successful completion of the oral skills portion would normally require prior training or professional experience in simultaneous and consecutive interpretation and sight translation. (February 14, 1985) (Emphasis added)

In sum, then, the AOUSC indicates that "training or professional experience" in interpretation would be necessary for most people to pass the Certification Examination. On the other hand, the Court Interpreters Act does not stipulate that pertinent training courses or programs be developed in order to prepare people to take the examination.

During a June 18, 1985 telephone conversation with Jon Leeth, Special Assistant to the Assistant Director of the Administrative Office of the United States Courts (AOUSC), he told the author that there has never been a budget for training and that no courses or programs are envisioned under the auspices of the AOUSC. In order to establish an AOUSC instructional program for those who wish to become federally certified court interpreters, the United States Congress would have to (1) mandate that the AOUSC train people; and (2) provide the funds to do so. Leeth also stated that, because the AOUSC is an administrative agency, it is highly unlikely that Congress would authorize it to train court interpreters. Of course, the lack of training at the federal level does not preclude the states from establishing programs of their own to meet the needs of their judicial systems.

\section{B. REQUIRED TRAINING FOR COURT INTERPRETERS}

\section{Qualifications}

Before a prospective interpreter can even think of undertaking training, he/she must be bi- or multi-lingual; that is, be able to express him/herself equally fluently in those languages he/she wishes to use in interpreting. In addition to a high level of competence in at least two languages, broad knowledge of the cultures in question is imperative. A candidate's personality is something that must be considered. Interpreters generally agree that one must be rather aggressive and extroverted, intellectually curious, and capable of dealing with the unexpected, among other things (Gerver and Sinaiko 1978; Henderson 1982; Schweda-Nicholson 1984; Seleskovitch 1978; Watson 1982).

\section{Course Content}

The very most basic content areas to be addressed in any court interpretation training course or program are:

(1) Development of simultaneous and consecutive (with and without notes) interpretation skills as well as sight translation and tape transcription techniques;

(2) Legal terminology;

(3) Understanding of the concepts behind the law;

(4) Courtroom procedure;

(5) The roles of the interpreter;

(6) Duties and responsibilities of the interpreter;

(7) Ethics, including confidentiality.

Training in simultaneous and consecutive interpretation, sight translation, and tape transcription is best obtained through a specialized course of study. A small number of court interpretation courses/programs currently exists (Schweda-Nicholson 1985b). As to the technique of teaching the requisite skills, much has been written. (See, for example: de Clarens, Lederer, and Weintraub 1973; Delisle 1981; Gerver and Sinaiko 1978; Herbert 1952; Rozan 1956; Schweda-Nicholson 1985a; and Seleskovitch 1978, 1975.) The professional interpreter is a well-trained, highly qualified person capable of providing 
a complete and accurate interpretation, whether at an international conference or in a courtroom (Schweda-Nicholson and den Tuinder 1984). Quite obviously, some overlap exists between the training of the conference interpreter and the court interpreter, most specifically in the area of mastering basic interpretation skills and technique.

Knowledge of legal terminology, the concepts underlying the law, courtroom procedure and the functioning of both the American and foreign legal systems is imperative (Berreby 1982; Frankenthaler and Zahler 1984: 87-88; Riva 1981).

When ad hoc court interpreters are used, the results are often disastrous. For example, in People v. Starling 21 III. App. 3d 217, 315 N.E.2d 163 (1974), an interpreter was required for a prosecution witness who spoke no English. The quality of the appointed interpreter's interpretation was so poor that the testimony was incomprehensible to all of the key courtroom participants (the judge, defendant, and attorneys). As well, in United States v. Pena 542 F.2d 292 (1976), the court appointed a Disney World interpreter to translate information on a consent-to-search form and the defendant's rights. Subsequently found guilty, the person appealed, stating he had not understood what happened during the trial. The Fifth Circuit, however, affirmed the judgement against him, indicating that the Trial Court record showed he had been advised of his rights in Spanish a number of times (Astiz 1980). One cannot help but question the quality of the interpretation with which the accused was provided. During a 1981 Miami drug smuggling trial in the United States District Court, the judge declared a mistrial after court had been in session for two days. A Spanish-speaking prosecution witness had been testifying through an interpreter. After listening to the interpreted testimony, seven Spanishspeaking members of the jury agreed that the interpreter had not been accurately translating what the witness was saying (Berreby 1982: 1). When the author questioned Jon Leeth of the AOUSC about this case, he stated that a federally certified interpreter had not, in fact, been used during the trial. At that time in Miami, there were not enough federally certified interpreters to handle the tremendous case load. Leeth added that the judge, who was visiting from another jurisdiction, had not worked with interpreters before. Without even ascertaining what the jurors objected to in the interpreter's translation, he declared a mistrial (Leeth, Personal communication, June 18, 1985).

\section{a. Court Interpreter Roles}

In the past, most courts have not distinguished between varying functions of court interpreters, although one early case, State v. Vasquez 101 Utah 444, 121 P.2d 903 (1942), did make a distinction between a "court" interpreter (one who interprets when, for example, a non-English-speaker testifies) and a "defense" interpreter (one who remains at the defendant's side during all proceedings, providing him/her with simultaneous interpretation of everything that is said in the courtroom). In a 1975 article, Chang and Araujo discussed three basic roles an interpreter may play in criminal proceedings: a "witness" interpreter, a "proceedings" interpreter, and a "defense" interpreter (1975: 802). According to the authors of the article, a "witness" interpreter aids at the stand when a non-English-speaking witness gives testimony. A "proceedings" interpreter helps the defendant hear and follow the colloquy among witnesses, the judge, and attorneys. Finally, a "defense" interpreter facilitates the defendant's communication with counsel.

With respect to standards for different roles an interpreter might play as outlined above, Bergenfield (1978: 563), employing the meaning given to "defense" interpreter in State v. Vasquez, states:

The standard [for a defense interpreter] can be low because the interpreter is not interposed between the defendant and the jury or the defendant and cross-examining lawyers. 
In the author's opinion, the standards for all court interpreters, no matter what categories or names one may devise to designate them, must be equally high. It is just as important for the defendant to understand what the judge says as it is for him/her to understand English- and non-English-speaking defense and prosecution witnesses. For due process, a defendant must be correctly and completely apprised of what is transpiring in the courtroom at all times. It does not seem logical that an interpreter who is translating testimony should be more competent than one who is constantly interpreting for the defendant during the entire proceedings.

\section{b. Ethics}

The importance of ethics, including confidentiality, cannot be stressed enough. As a result of the formal nature of courtroom proceedings and the seriousness of the potential consequences, instruction in ethics must be included as an integral part of any court interpreter training program.

Fortunately, a number of excellent codes of ethics for court interpreters currently exist. The Preamble to the California Court Interpreters Association (CCIA) Code of Ethics very effectively describes the interpreter's critical contribution to courtroom proceedings:

The court interpreter, as the only medium of communication between the parties involved, plays a vital role in the administration and preservation of justice. The fulfillment of this part requires an understanding by the interpreter of the difficult task to be performed, and the fundamental ethical principles to be obeyed (n.d.: 1).

As well, the Code of Ethics of the court interpreters in the Los Angeles County Superior Court includes a section entitled, "Standards of Court Conduct and Professional Responsibilities" (Almeida and Zahler 1977: 6-13). The Agricultural Labor Relations Board Interpreter Code of Ethics of the State of California is based on the CCIA Code of Ethics and also on Section 18.3 of the Standards of Judicial Administration Recommended by the Judicial Council of California. There is no code of ethics issued by the AOUSC for the federally certified Spanish/English court interpreters. The above codes of ethics discuss such relevant topics as conflicts of interest, confidentiality, how to interpret during testimony, and the importance of continuing education to constantly upgrade skills and knowledge. Court interpreters are also ethically bound to accept only those assignments for which they are qualified, to correct any mistakes that are made immediately, to interpret verbatim what is being said, and not to paraphrase or explain. The goal of court interpretation is for the defendant to hear the trial as he/she would hear it if the trial were being conducted in his/her native language. The Court Interpreter's Manual of the Court of Common Pleas and Municipal Court, City of Philadelphia states:

[T] $\mathrm{T}$ interpreter's job is to interpret everything which the defendant, judge, attorneys, or others present would understand if no language barrier existed (n.d.: 1) (emphasis in original).

(For more discussion of this issue, see Carrizosa 1984: 15; Frankenthaler and Zahler 1984: 85; and "Court Interpreting: From Nice Little Ladies to Navahos" 1984; 2.)

If one aims, then, for the goal of native language equivalence, it is important not to go beyond it through explanation or paraphrase. Dena Kohn states:

The interpreter must never and should never edit, select and improve. A good interpreter repeats nonsense when it is nonsense, repeats lucidity if it's lucidity (Berreby 1982: 3). 
One must remember that many Americans whose native language is English have great difficulty following legal language and understanding the concept behind the law. In this connection, the non-English-speaker should not have an advantage over the Englishspeaker in courtroom proceedings through explanations and clarifications provided by an interpreter. Astiz (1980: 3) writes:

I do not believe that the criminal justice system should do for the non-English speaking individual what it does not do for the English speaking majority; in other words, deficiencies... in the criminal justice system that are not caused by somebody's inability to speak English, can not be solved for a certain group only.

Finally, Judge Ricardo M. Urbina of the Superior Court of the District of Columbia, the only Hispanic judge in the city of Washington, addressed himself specifically to Hispanics' encounters with the courts:

We are not trying to give Hispanics more than what they deserve. We just want to bring parity into the criminal justice system where Hispanics are concerned (Valente 1983: A-12).

The case for court interpreter training can only be further strengthened by citing several examples of unethical behavior. The judge, jury, and attorneys assess the credibility of a non-English-speaking witness not only through his/her demeanor but through the interpreter's language and demeanor as well (see, for example, Bergenfield 1978: 552). In United States v. Anguloa 598 F.2d 1182 (1979), some difficulties arose while the defendant was testifying through an interpreter. ${ }^{1}$ The judge suggested that the prosecutor and interpreter proceed "slowly and bit by bit" (1184). In response to the judge's request, the interpreter states: "It's not necessarily the questions. It's the way the defendant changes the subjects into different things at times" (1184). The judge then instructed the interpreter to provide a literal translation of what the defendant was saying. The interpreter responded: "He says a lot of mumbo-jumbo that doesn't mean a lot of things" (1184). The judge, of course, ordered that the interpreter's disparaging remarks about the defendant be stricken from the record. However, the jury did hear these negative statements. The judge was concerned about the jury allowing the remarks to influence its assessment of the defendant's credibility. The judge dismissed the interpreter and replaced her with a new one. Before the trial continued, however, the judge instructed the jury:

Obviously, an Interpreter is not a participant in the trial. An Interpreter really only acts as a transmission belt or telephone. In one ear should come in English and out comes Spanish... [A]ny remarks, if any she did make, with respect to the witness other than translating his answers or his statements as best she could or as best she thought she could, you must disregard entirely (Reporter's Transcript: vol. III, pp. 105-107).

As well, in People v. Starling, the interpreter was frequently reprimanded by the judge for carrying on personally initiated conversations with the accused. The above examples clearly illustrate why training in courtroom ethics must be included in any court interpretation course of study.

\section{CONCLUSION}

The current article has cited numerous instances of ad hoc interpreter use in the American courts. As illustrated, these "interpreters" usually do not demonstrate the necessary foreign language competence, skills in simultaneous and consecutive interpretation, and knowledge of the law and courtroom proceedings, nor do they have an understanding of the very critical ethical considerations involved. As a result, one immediately questions whether the non-English-speaking defendant's rights to due process (confronta- 
tion of witnesses, cross-examination, and participation in one's own defense) are protected. In an attempt to remedy this unfair situation, the present study has called for professional court interpreter training. The requisite knowledge and skills do not spring forth ex nihilo if one wishes to become a court interpreter. Specialized courses would be one way to attack the problem of inferior interpretation services in this area. In addition to providing evidence which undeniably supports academic preparation for court interpreters, the article has also outlined the basic content areas which must be treated in any comprehensive training program.

Court interpreter training is not the only change that is needed. Judges, attorneys, bailiffs, clerks of the court, and so on must be educated as to the interpreter's functions, duties, and responsibilities. In this connection, courtroom personnel must become aware of the required high level of both English and foreign language competence on the part of the interpreter. As well, those who work in the courts have to become more cognizant of the need to employ trained interpreters who have knowledge of courtroom procedure and legal terminology. "Employ" is the key word in the previous sentence. As mentioned earlier, many well-intentioned courts rely on volunteers to provide interpretation because no money has been budgeted for such services. We must all work to develop an awareness among the judiciary that paid professionals are required to provide complete and accurate interpretation.

In addition to educating the judiciary, other steps must be taken. It is a well-known fact that legislation and/or judicial action addressing the issue of court interpretation is desperately needed in the overwhelming majority of states. (Some states such as New York and California already have court interpreter certification programs, but the quality of these testing procedures is questionable (see Astiz 1980; Berreby 1982; SchwedaNicholson 1985b). State legislation could easily be modeled on sections of the Court Interpreters Act. As mentioned before, a shortcoming of the Act is that it makes no provision for training interpreters. The author suggests that the states take this factor into consideration when proposing and developing court interpreter legislation and allot funds for the express purpose of training. At present, the New Jersey Supreme Court Task Force on Interpreter and Translation Services is contemplating such a measure (Lee 1983; Project Outline 1982).

Perhaps it is too idealistic to hope that the use of ad hoc interpreters can be eliminated from all segments of our judicial system. However, by educating the judiciary and working for legislation which addresses this issue in a comprehensive manner, we can make great strides. All persons deserve fair and equal treatment in our courts. This right is guaranteed by the Federal Constitution. To ensure equality under the law, we must strive to provide non-English-speakers with quality interpreters.

\section{Note}

1. Even though this was a federal case, it should be noted that the interpreter was not federally certified. The AOUSC's examination for certifying Spanish/English court interpreters was in the process of development in 1979 and was not pilot-tested until November of that same year. As a result, the initial round of official testing to select the first group of federally certified interpreters was not held until 1980.

\section{REFERENCES}

ALMEIDA, Frank M. and Sofía ZAHLER (1977): Los Angeles Superior Court Interpreters Manual, Los Angeles, Los Angeles County Superior Court.

ALRB Interpreter Code of Ethics (1983): Sacramento, CA, Agricultural Labor Relations Board.

ANDERSON, R. Bruce W. (1978): Interpreter Roles and Interpretation Situations: Cross-Cutting Typologies. Language Interpretation and Communication, David Gerver and H. Wallace Sinaiko (eds.), New York, Plenum Press, pp. 217-230. 
Announcement: Court Interpreters Certification Written Examination, Spanish/English. February 14, 1985. Washington, D.C., Administrative Office of the United States Courts.

ARJONA, Etilvia (1983): "Language Planning in the Judicial System: A Look at the Implication of the U.S. Court Interpreters Act," Language Planning Newsletter, 9: 1, pp. 1-6.

ASTIZ, Carlos (1980): Language Barriers in the Criminal Justice System: A Look at the Federal Judiciary. Paper read at the National Hispanic Conference on Law Enforcement and Criminal Justice, Washington, D.C., July $27-30$.

BERGENFIELD, Glenn (1978): "Trying Non-English Conversant Defendants: The Use of an Interpreter," Oregon Law Review 57: 4, pp. 549-565.

BERREBY, David (1982): "Interpreters on Call for More Cases," The National Law Journal, 5: 15, December 20 , p. 1.

CARRIZONA, Philip (1984): "High Court Defines Defendants' Right to Own Translator," The Los Angeles Daily Journal, 97: 71, April 6, pp. 1, 15.

CHANG, Williamson, B.C. and Manuel U. ARAUJO (1975): "Interpreters for the Defense: Due Process for the Non-English-Speaking Defendant," California Law Review, 63: 3, pp. 801-823.

Code of Ethics (n,d.): California Court Interpreters Association.

Court Interpreters Manual (n,d.): Philadelphia Court of Common Pleas and Municipal Court.

"Court Interpreting: From Nice Little Ladies to Navahos" (1984): The Capital Translator, V: 6, June 12, pp. 1-2.

DE CLARENS, J., M. LEDERER and E. WEINTRAUB (1973): "Enseigner l'interprétation," Études de linguistique appliquée, 12, pp. 110-126.

DELISLE, Jean (ed.) (1981): l'Enseignement de l'interprétation et de la traduction, Ottawa, University of Ottawa Press.

"Editorial" (May 10, 1983): The Washington Post, A18.

FELDMAN, Paul (1985): "L.A. Courtrooms: Judge, Jury — and Interpreter," Los Angeles Times, May 5, A1.

FRANKENTHALER, Marilyn and Sofía ZAHLER (1984): "Las Características del Lenguaje Jurídico en el Ambito Legal," Revista de Lengua i Dret, 2: 3, pp. 77-88.

FRANKENTHALER, Marilyn (1982): Working with an Interpreter: A Guide for Professionals, Upper Montclair, New Jersey, Montclair State College.

GARLAND, Susan (1981a): "Hispanic Court Cases: The Verdict is All in the Translation," The Christian Science Monitor 74 (8), December 7, p. 1.

GARLAND, Susan (1981b): "Easing the Plight of Non-English-Speaking Defendants," The Christian Science Monitor, December 9, p. 18.

GERVER, David and H. Wallace SINAIKO (eds.) (1978): Language Interpretation and Communication, New York, Plenum Press.

Glossary of Terms Used in the Federal Courts (1980): Washington, D.C., Administrative Office of the United States Courts.

HENDERSON, John (1982): "Some Psychological Aspects of Simultaneous Interpreting," The Incorporated Linguist, 21: 4, pp. 149-152.

HERBERT, Jean (1952): Manuel de l' interprète, Geneva, Georg.

HIPPCHEN, Leonard J. (1977): "Developement of a Plan for Bilingual Interpreters in the Criminal Courts of New Jersey," The Justice System Journal, 2, pp. 258-269.

INGRAM, Robert M. (in press): Sign Language Interpretation and Public Policy in the United States. Languages in the International Perspective, ed. by Nancy Schweda-Nicholson, Norwood, New Jersey, Ablex Publishing Corporation.

LATIMER, Leah Y. (1983): "Translators Play Growing Role in Area Police Departments," The Washington Post, July 5, B-1.

LEE, Robert J. (1983): Equal Access to Justice for Linguistic Minorities: A Model for Policy Development The New Jersey Approach. Speech read at the Court Interpreters and Translators, Inc. Annual Meeting, November 20.

MARRONE, Claire (1982): The Use of Interpreters in Municipal, State, and Federal Courts: Wilmington, Delaware and Philadelphia, Pennsylvania. Unpublished manuscript.

Project Outline of the New Jersey Supreme Court Task Force on Interpreter and Translation Services (1982): Trenton, New Jersey, Administrative Office of the Courts, State of New Jersey.

RIVA, Nina (1981): "Droit public et traduction," META, 26:3, pp. 223-228.

ROBERTS, Roda (1981): l'Interprétation auprès des tribunaux, Ottawa, University of Ottawa Press.

ROZAN, J.F. (1956): la Prise de notes en interprétation consécutive, Genève, Georg.

SAFFORD, Joan Bainbridge (1977): "No Comprendo: The Non-English-Speaking Defendant and the Criminal Process," Journal of Criminal Law and Criminology, 68, pp. 15-30.

SCHWEDA-NICHOLSON, Nancy (in press): Languages in the International Perspective, Norwood, New Jersey, Ablex Publishing Corporation.

SCHWEDA-NICHOLSON, Nancy (1985a): "Consecutive Interpretation Training: Videotapes in the Classroom," META, 30:2. 
SCHWEDA-NICHOLSON, Nancy (1985b): Court Interpreter Training: A Growing Need. Paper read at the Fourth Annual Eastern Michigan University Conference of Languages for Business and the Professions, Dearborn, Michigan, May 2-4. (Proceedings volume available through the ERIC Microfiche Collection.)

SCHWEDA-NICHOLSON, Nancy (1984): An Interpretation Career: A Viable Alternative for the Foreign Language Student. Paper read at the South Atlantic Modern Language Association Annual Meeting, Atlanta, Georgia, November 8-10.

SCHWEDA-NICHOLSON, Nancy and Johanna den TUINDER (1984): "Semantics and Context in Simultaneous Interpretation," in Silver Tongues: Proceedings of the 25th Annual Conference of the American Translators Association, ed. by Patricia E. Newman, Medford, New Jersey, Learned Information, Inc. pp. 383-389.

SELESKOVITCH, Danica (1978): Interpreting for International Conferences, Washington, D.C., Pen and Booth.

SELESKOVITCH, Danica (1975): Langage, langues et mémoire, Paris, Minard.

SOLLMANN, Mariana (1984): Court Interpretation in the Courts of Wilmington. Unpublished manuscript.

VALENTE, Judith (1983): "Hispanics Lack Parity in Court System," Washington Post, May 5, A1, A12.

WATSON, Hilde (1982): "Conference Interpreting," The Incorporated Linguist, 21: 4, pp. 139-141. 